\title{
Core Device
}

National Cancer Institute

\section{Source}

National Cancer Institute. Core Device. NCI Thesaurus. Code C49893.

A rod that sits within a coil, or a general term referring to the central, main part of a device. 